\title{
Transnational Spaces in Amitav Ghosh's The Circle of Reason
}

\author{
Ajay K. Chaubey \\ Assistant Professor (English) \& Head, Dept. of Humanities and Social Sciences, National Institute \\ of Technology, Uttarakhand, India. E-mail: kcajay79@gmail.com. ORCID ID 0000-0002-6413-798
}

\begin{abstract}
This essay maps the unmapped nuances of transnational/cultural spaces in Amitav Ghosh's debut novel, The Circle of Reason (1986; 2008), which underscores the inter-territorial itinerary of Alu, the protagonist, who after being accused of being a terrorist, runs from Lalpukur, near Calcutta (now Kolkata) to Goa to AlGhazira, a fictional gulf-state and finally to Algeria. The novel, Bildungsroman in nature and thematic treatment, poignantly deals with James Clifford's idea of 'assimilation' (of) / 'travelling' cultures, geo-political boundaries and hybridization of language. The rationale of the paper is to deconstruct the binariestradition and modernity; oriental and occidental cultures; and emigration and immigration, which are, to me, the themes of the narrative of the novel. Ghosh has dexterously intertwined the cultural matrix of different spaces in the novel to show how in this age of mobility, open economy and transnational migration, transcultural awareness is all to value. This essay also traces the trajectory of mobility in the age of fluidity and underpins patterns of movement which affect cultural orientations, sensibilities, and, consequentially, creative expressions.
\end{abstract}

Keywords: Spatial shifting, Homi K Bhabha, James Clifford, and multiple identities, etc.

"Transnationalism seems to be everywhere..." (Vertovec, 2009, p. 1).

"In a story about his travels to Egypt and other parts of the globe, Amitav Ghosh discovers that the male members of an isolated village are as travelled as any metropolitan and elite jet-setters"

(Ashcroft, 2012, p. 130; emphasis original).

The aforementioned epigraphs evidently reverberate about the nuanced and unmapped journey of an individual who voyages from one place to the other in a search for his/her sustenance or shelter. Man has travelled ever since his genesis on the planet thanks to his banishment from the Elysium for 'tasting the fruit of knowledge.' This banishment charts his movement from one territory to the other and also draws his struggle for an identity formation. This also constitutes epistemological textures of a human which is a matter of critical inquiry. In such cases, some drifters dissent while some assimilate into the host-land/culture/ambience and if discontented, they move to the other 'location of culture' for procuring temporal power. To quote Bhabha (1994) in this context: "Our existence today is marked by a tenebrous sense of survival, living on the borderlines of the 'present', for which there seems to be no proper name..." (p. 1). This pallid protrusion of an individual's 'existence' has been postulated by the authors of the South Asian origin in their fictional stories from time to time and Amitav Ghosh is not an exception to 
framework the catastrophes in human society — for survival or for knowledge —in overt and covert manner; within or beyond one's geographical spaces.

This essay ${ }^{1}$ is a humble attempt to address the illustration of transnational spaces in the Ghosh's debut novel, The Circle of Reason (henceforth $C R$ in parenthetical citations; 1986). This novel underscores the inter-territorial itinerary of Alu, a.k.a. Nachiketa Bose, the protagonist, who after being falsely accused of as a terrorist, runs away from Lalpukur, near Calcutta (now Kolkata) to Goa to Al-Ghazira, a fictional gulf-state and finally to Algeria. The novel, Bildungsroman in nature and thematic treatment, poignantly deals with James Clifford's idea of 'travelling' cultures, geo-political boundaries and hybridization of language. The rationale of the paper is to deconstruct the binaries-tradition and modernity; oriental and occidental cultures; and emigration and immigration, which are, to me, the themes of the narrative of the novel, The Circle of Reason.

Ghosh has adroitly intertwined the cultural matrix of different spaces in the novel to show how in this age of mobility, open economy and transnational migration, transcultural awareness is all to be valued and assessed from time to time. This essay also traces the trajectory of mobility in the age of fluidity and underpins the patterns of movement which "affect cultural orientations, sensibilities, and, consequentially, creative expressions" (Dagnino, 2013, p. 130). The fictional realms of Amitav Ghosh do not only buttress on the space as a place of contact but also on the space as a conflict as well as character. Ghosh induced his expedition of artistic feats with The Circle of Reason, which accentuates inter-continental and transcultural/national journey of Alu, a young weaver, who hails from a rural segment of Bengal. The present paper is an attempt to trace the linear itinerary of the fictional characters wandering as nomads from one nation to the other. What is palpable in taking the debut novel of Ghosh is to study the transnational ambiance and to cognize, the anthropological issues in novel, which unfold the psyche of the novelist from the very beginning of his literary career. The novel, which won the prestigious Prix Médicis étranger, a French literary award in 1990, beautifully paints the canvas of rural Bengal during the natality of a new nation, Bangladesh, in 1971. The paper would also address some questions related to transnationality, transculturality, migrancy as to how far Alu, the protagonist, was forced to migrate from the 'mother' to the 'other' land. How his diasporic sense was framed during his immigration not only to one nation but also to the many nations in the quest for protecting his own life from compelling situations.

Since Ghosh is a cosmopolitan author, critic, sojourner and environmentalist of international recognition, he has invited the attention of international critics who have worked more meticulously on his works than Indian scholars per se. Yumna Siddiqui (2002); Claire Chambers (2003); John C. Hawley (2005); Anshuman Mondal (2010); Chitra Sankaran (2012) and many more have disseminated the groundbreaking works on Ghosh's literary oeuvre. Siddiqui's elongated essay entitled, "Police and Postcolonial Rationality in Amitav Ghosh's The Circle of Reason"2 explores "the ambivalences of postcolonial modernity" (p. 14) whereas Chambers' unpublished thesis entitled The Relationship between Knowledge and Power in the Works of Amitav Ghosh (2003) the first monograph till 2003, "attempts to fill a critical gap by providing a sustained account of Ghosh's writing" (p. iii). These works are followed by Hawley's critique, Amitav Ghosh: An Introduction (2005), which deals with Ghosh's personal, academic, journalistic and creative accounts. Additionally, Mondal's treatise on Ghosh is "an authoritative critical 
introduction to the fictional and non-fictional writings of ...Ghosh" (blurb). Therefore, it is evident that Ghosh's writings have preoccupied not only the literary scholars, but also the scholars of sociology, anthropology, environmental and Diaspora studies.

Being an Anthropologist by intellectual training, Ghosh endeavors to fill gaps between despairing peoples of multiple ethnic backgrounds and locations, and communities in his narrative structure to exhibit the nuances of what Said says, "overlapping territories and intertwined histories" (Butt, 2008, p. 3). In socio-cultural, historico-political and literary productions, moving from one place to another, in search of livelihood, is treated as diasporic manifestation. The trans/location/cultural/national is the term/s, which is interchangeably connected with diaspora overtly and covertly because one who leaves one's native land is both transnational and diasporic as well. William Safran in his seminal essay "Diasporas in Modern Societies: Myths of Homeland and Return" (1991) juxtaposes the word diaspora with other related categories. He records that the expression is now used to describe different categories of peopleexpatriates, expellees, political refugees, alien residents, immigrants, ethnic and racial minorities, refugees and other comparable groups. Safran in his article begins with Walker Connor's definition of diaspora, where Connor uses it as kind of an umbrella term to connote "that segment of a people" who are "living outside their homeland" (Connor qtd. in Safran 84). Safran (1991) extends Connor's definition and specifies few characteristics for the diasporic existence and charts the following characteristics:

1) they, or their ancestor, have been dispersed from a specific original "center" to two or more "peripheral" or foreign regions; 2) they retain a collective memory, vision, or myth about their original homeland-its physical location, history, and achievements; 3) they believe that they are not and perhaps cannot be - fully accepted by their host society and therefore feel partly alienated and insulated from it; 4) they regard their ancestral homeland as their true, ideal home... 5) they believe that they should, collectively be committed to the maintenance or restoration of their original homeland and its safety and prosperity; and 6) they continue to relate, personally or vicariously, to that homeland in one way or another. (p. 86)

Robin Cohen in his Global Diasporas (1997), on the other hand, commends Safran's definition and advances it further adding a rejoinder to it. Cohen affirms that since the 1980s, the term has been used to describe "different categories" of people, creating a "varied cluster of diaspora," since these groups with their different historical experiences and collective narratives prove that diaspora is a more problematized term in the contemporary world. To make it even more elaborative, Floya Anthias (1998) demands a thorough revision of the term as it tends to homogenize the populace from one home country to the other, completely overlooking their internal ethnic differences. She writes:

The lack of attention given to trans-ethnic solidarities, such as those against racism, of class, of gender, of social movements, is deeply worrying from the perspective of the development of multiculturality, and more inclusive notions of belonging. For a discourse of antiracism and social mobilization of a trans-ethnic (as opposed to a transnational) character, cannot be easily accommodated, within the discourse 
of the diaspora, where it retains its dependence on 'homeland' and 'origin,' however, configured. (p. 12)

A lack of attention to the internal divisions of the communities results in overlooking the possibility of transcultural negotiations between two or more communities. The Indian diaspora is fairly affected by this lack of introspection too. Most of the critics brooding on the subject of the Indian diaspora, including Cohen himself, keep the Indian diaspora mainly under the "trade" and "labor" categories of the diaspora. Additionally, the most canonical Indian diasporic writers, including Naipaul from the 'old' diaspora and Rushdie, Lahiri, Baldwin, and Ghosh from the 'new' diaspora, fall under the aegis of these broad categories. The latter are such authors who are permanently settled in abroad, but Ghosh is an exceptional one who often divides his time between India and the US. However, this issue is elided in the novel, $C R$, undertaken for the study.

What makes Ghosh a perfect novelist is his transnational visits, transcultural awareness, and his transluscent tenets over global societies, and to comprehend this thesis, he can be referred in the following quote:

Human beings have woven and traded in cloth from the time they built their first houses and cities. Indian cloth was found in the graves of the Pharaohs. Indian soil is strewn with cloth from China. The whole of the ancient world hummed with the cloth trade. The Silk Route from China, running through central Asia and Persia to the ports of the Mediterranean and from there to the markets of Africa and Europe, bound continents together for more centuries than we can count. It spawned empires and epics, cities and romances. Ibn Battuta and Marco Polo were just journeymen following paths that had been made safe and tame over centuries by unknown, unsung traders, armed with nothing more than bundles of cloth. It was the hunger for Indian chintzes and calicos, brocades, and muslins that led to the foundation of the first European settlements in India. All through those centuries cloth, in its richness and variety, bound the Mediterranean to Asia, India to Africa, the Arab world to Europe, in equal, bountiful trade (Ghosh, 2008, p. 59-60).

As Ghosh has travelled as well as lived in different spatial locations, his imagination becomes purely diasporic. However, he remains an Indian even though he had lived and researched in Sri Lanka, Burma, Oxford, Pennsylvania, and New York among other countries. His rootedness is still found in the suburbs of Bengal which has been compelling force for the journey of writing this novel, CR. Jasbir Jain (2015) remarks, "Amitav Ghosh writes about Bengal, but the location is not identified by any one city. He moves across space both inside the country and outside it" (p. 225). Ghosh (1989) himself clarifies, about his multiple visits to many nations as a student, researcher, Anthropologist and finally as a novelist, in his essay entitled, "The Diaspora in Indian Culture": "...diasporic Indians take with them not so many things, but they carry processes...India exported with her population...not a language, as other civilizations have done, but a linguistic process...the process of adaptation of heteroglossia" (p. 74). Ghosh is of the opinion that such 'demographic dislocations' are not only the part of the diaspora but also an important 'force of world culture.' Earlier such 'culture' was confined to the Indian subcontinent only but, in the early nineteenth century, thanks to the British colonialism, the movement crossed "the Black Atlantic" for sugar cane farming. The ancestors of V S Naipaul were the part of such diasporic movements that have 
been fictionalized by Ghosh in his major works, which deal with multiple locations of the different parts of world ${ }^{3}$ and The Circle of Reason is not an exception of transnational/cultural exposés of the subaltern characters.

The Circle of Reason, a novel that highlights the colonial heirlooms and encounters binaries, occupies a coveted place in the galaxy of postcolonial novels across the globe. Ghosh alludes to the political ideologies of the West that assisted in sustaining the western myths of progress, rationality, Enlightenment and history of 'scientific reason', against superstitions, irrationality, and illiteracy and proscribed exodus prevailing in Indian societies. The novel is tripartite, which quantify-Satwa (Reason); Rajas (Passion) and Tamas (Death) (See de Lemos, 2016; Goh 2012). The novel, set around Alu because of his potato-shaped scalp, and because of his escape from India, to the Middle East and finally to Africa in a crisscross way, brings a transnational/cultural shape in the plot of the novel, as he moves from one nation to the other and encounters local culture/s. This transnationality entices the readers to delve deep into the labyrinth of the novel's superstructure. It also reflects the transnational journey of Ghosh and his erasure of boundaries in his novels which, often, places the characters 'liminal' spaces. It is also critiqued that Ghosh intentionally knits the plots of his novels to clearly convey the message of 'vasudhaiv kutumbkam' as it is our physical movement that keeps our body confined within the coterie of physical boundaries while factually the "imaginary homeland" and expurgation of physical boundaries are always 'present' in the psyche of the readers/characters of Ghosh.

On the other hand, Arianna Dagnino, a pioneering theorist of 'transculturalism', through her exhaustive and comprehensive essays displays that she has written over the decades, and the same have been merged in her well-researched book entitled Transcultural Writers and Novels in the Age of Global Mobility (2015). ${ }^{4}$ Her critique of 'transnationalism' differs and defers from the critics and theorists mentioned above. Dagnino (2015) writes that,

We are living in an age of increasing interconnectedness, where political borders and cultural edges tend to blur, and growing numbers of people throughout all layers of society are "on the move" across the planet, experiencing the effects of dislocation, deterritorialization, and cross-cultural acculturation (or transculturation). Hence, we have the growing influence of views and approaches related to transnationalism, flexible citizenship, neo-nomadism, neocosmopolitanism (in its rooted, situated, or vernacular variants), or transculturalism (p. 1).

Further, Dagnino, in many of her essays, opines that transculturalism is an emerging subject matter thanks to 'growing transnational mobility' and 'denationalizing wave of globalization' but, Inez Baranay (2016), on the contrary, an Italian born Australian writer and academic, in her essay entitled "Transcultural Space and the Writer" postulates that "in transcultural space, every outsider is an insider, and everyone belongs because of their non-belongingness" (p. 2-3). This 'outsiderinsider' syndrome thematically embedded in the novel when the fugitive protagonist of the novel, Alu, who is trapped in the cobweb of two epistemological clashes-the critical thinking, rational notion, on one hand, nurtured, nourished and exhilarated by Balaram, a school teacher while superstition, irrationality, and arbitrary thinking, on the other hand, exhilirated by Bhudeb, a wealthy man of Lalpukur. Balaram's proclivity for knowledge and rationality is evident whereas 
Bhudeb yearns for mundane power and prominence in coexisting society, depicted by Ghosh in $C R$. Balaram, while elaborating the significance of science, asserts, " $[\mathrm{A}]$ science can tell you about things as they are; not about what they might become" (p. 22). Balaram's interests in pursuance of knowledge are everywhere, and this surprises Alu because he wanted to read what Balaram has already read, "[H]istory, geography, geology, natural history and biology...anything at all...." (Ghosh, 2008, p. 28). Moreover, his yearn for the biography of Louis Pasteur, C V Raman, and Phrenology decrees that his dedication to education is par excellence. Balaram educated from the prestigious Presidency College, which played a crucial role in fuelling intellectual climate in the nineteenth century Bengal, in his devouring inclinations for wisdom against wealth, attempts to consort with Bhudeb Roy as the latter intends to kill Alu.

Needless to mention that we still transmit the 'white men's burden' and intend to unfollow the colonial modernity regarding our educational system which Ghosh essays to articulate in $C R$. Ghosh also displays how colonial didactic system prevails to subdue the Indian persona who transports the western legacy, and by doing so, he portrays Balaram who craves for being the champion of western sciences. Further, Ghosh questions the impact of western sciences through Balaram who embodies the same and "uncritically subscribes to its metanarrative" (Das, 2013, p. 172).

Bhudeb Roy, in sharp contrast with Balaram, having six sons, is not only an owner of the school where Balaram teaches but also a muscle man, anti-populist sponsor of ignorance over knowledge. Roy once planned a puja to goddess Saraswati to liaison with the Inspector of Schools. Balaram caused fracas as it remarking that it is Roy's narcissism, rather than his cravings for knowledge to worship the Muse. In response, Bhudeb Roy poisons fish in Balaram's pond and five of his sons attack Balaram's servant Maya. In this incident Alu, who was eleven years old at that time, ran and fetched Maya's brother who defended her from rape. In the entire series of feuds, the victim, at large, was none other than Alu. After the blast happened in the house of Balaram, which signifies the blowing of the 'presence' of 'knowledge,' forced Alu to escape with the help of Bolai-da:

Alu began to run again. His whole mind went blank, except for the rhythm for his pounding feet. Exasperated...Alu slumped over.... I (Bolai-da) will see you safe somewhere...Alu, stumbling...inert and uncomprehending, could only see the flames of the unknown world licking the skies (Ghosh, 2008, p. 160).

Alu escapes to Mahé, which is not part of Kerala, but actually "heading south, towards Kerala" (165), another cultural territory-an antinome to Bengali culture and location.

The second part of the novel percolates around Zindi-at-Tiffaha who helps the Indian community in the Middle East. Alu voyages for al-Ghazira with Zindi. All the fellow travellers on the steamer, Mariamma, have been dislocated from their native place (Ghosh, 2008, p. 181). They migrate to another country for better prospects than they had in their country of origin. Ghosh asserts, "it seemed to me sometimes that everyman in it is a traveller" (p. 135). Such kind of movement from one nation to another is observed by Ashcroft (2012) differently: "the paradox of global culture is that it makes itself 'at home' in motion rather than in place" (p. 130). It is, therefore, evident that the present global force has been marked by a diasporic movement from developing nations to the developed countries to re-shape the 'identity' of an individual and, Alu 
is not an exception. His transnational migration to escape the police and his 'assimilation' in the societal pattern of the Middle East happens situationally, and not by choice. Paul Sharrad (2012) judiciously observes in his essay:

Ghosh's novel illustrates...globalized postmodernity ...of a single narrative of modernization but of co-existing and conflictual time-spaces, so that the construction of a mammoth palace of consumerism occurs in The Circle of Reason...with a social protest expressing itself as a subaltern religious cult (p. 219).

Alu's escape from one nation to the other baffles one's mind whether he is in a 'world' of his own or he belongs to the 'worlds' of others. Given his diasporic 'self,' sense and sensibilities, I would refer the way Ragini Tharoor Srinivasan (2011) posits a question, "Are diasporic doers of -a "world", -the "world", -this "world," or - "worlds"? Is the diasporic subject of history between worlds? Or ... does every human subject dwell between? - [Take] away from the cartography of betweenness... and along with it, vanishes the human subject...." (p. 50). Alu's 'refugee' status disrupts "the tidy view of nation, narration, and belonging," (p. 147) write Bose, Sahoo and Lal (2009) in their essay "Home and Away". The unceasing journey of Alu in the form of forced migration evidently iterates the 'flux' in the diasporic itinerary. The police officer Jyoti Das, a metaphor of cataclysm in the host land, acts as a shadow of Alu as the former pursues the latter, wherever he verves. On the contrary, Alu's narrow escape from the debris where he is buried alive in the wrecked building where he works as a labourer symbolizes the Foucauldian 'govermentality' ${ }^{5}$ and panopticism ${ }^{6}$ with which all the diasporan traverse for power and plenitude.

Thus, The Circle of Reason reflects binaries throughout. A transnational move is a promising step for pecuniary pursuits but engulfs the itinerant in identity crises. Ghosh represents the jeopardies of millions of Indians living in the Middle East for placid senility, but sometimes the unlawful acts of the diasporans invite the catastrophe in the form of Jyoti Das which keeps on chasing till the perpetrator like Alu is trapped. Kavita Daiya (2008) remarks:

Focusing on a motley group of illegal migrants drawn from various parts of India who travel to the imaginary Gulf state al-Ghazira and then Algeria, the novel (The Circle of Reason) depicts the struggle for survival of those displaced by dispossession in globalisation: people whose very bodies bear the violent marks of this historical passage (p. 392-93).

If one looks at the situation of the protagonist, one finds that his (Alu's) transnational locomotion provides the novel a sanguine closure. Diasporic sensibilities of the host of other characters whom Alu meets on the boat en route-Zindi, Karthamma and her baby Boss, Kulfi, Chunni, among others reverberate the "hope" in their 'collective consciousness' that the 'return' gives rejoice. Ghosh writes: "[w]hen the time came, they (Alu and Zindi) walked with Jyoti Das....As he (Das) walked away, they waved and waved at his back....He (Das) laughed. Alu waved, and he waved back" (p. 456). Seeing this situation one can question whether they are returning to their homeland or they are rejoicing their return in imagination? Robin Cohen (2007) postulates a similar question in his essay: "Do We Need a Homeland in order to Conceive of a Diaspora?" he further argues, "even asking this question may have seemed absurd to the older generation of scholars and to those who pioneered the growth of diaspora studies in the 1990s. It was, in one sense, logically and etymologically impossible" (p. 2). As the title of the novel is very symbolic that Ghosh talks 
about the 'circle.' In a circle, when one starts from the points he comes back to the point. After all the movements, one comes back to the same point. So, sometimes it is not possible that transnational migrant comes back to the same position physically but imaginatively. Rushdie (1991) writes, "...the imagination works best when it is most free." (p. 20)and hope remains the vehicle through which a transnational migrant could travel in imagination. Ghosh ends the novel by foregrounding faith in optimism: "Hope is the beginning..." (p. 457) and hope is foci for transnational migrants including Alu a.k.a Nachiketa Bose which eymologically means "the one who does not let his energy be lost in an endless loop." ${ }^{17}$

\section{Notes}

1. Part of this paper was presented in the International Conference on "In Search of the Hero/es within the Genre and Beyond" during February 23-24, 2018 organized by Dept. of English, MMV, BHU, Varanasi, UP, India. It is further declared that this paper has not been submitted elsewhere for publication in any form-electronic or print.

2. First published in Cultural Critique, No. 28 (Winter 2002): 175-211 and reprinted in Amitav Ghosh: Critical Essays. Second Edition. Ed. Bibhash Choudhury. New Delhi: PHI, 2016. 14-44. Print. My references are from the latter one.

3. Major novels of Ghosh are spread over many locations, nations and ethnic societies. For more details, see footnotes of Butt's "Inventing or Recalling the Contact Zones? Transcultural Spaces in Amitav Ghosh's The Shadow Lines." Postcolonial Text Vol. 4.3 (2008): 1-16.

4. I humbly acknowledge the academic support of Arianna Dagnino, Lecturer at the University of British Columbia, Vancouver [Canada] for personally sending me her e-book entitled Transcultural Writers and Novels in the Age of Global Mobility (Purdue University Press, 2015), on my personal request to her through e-mail.

5. 'Governmentality' is a concept first developed by the French philosopher Michel Foucault in the later years of his life, roughly between 1977 and his death in 1984, particularly in his lectures at the Collège de France during this time. Source: https://en.wikipedia.org/wiki/Governmentality. Accessed on Feb. 11, 2018

6. For more details, visit: http://www.michel-foucault.com/concepts/index.html. Accessed on Feb. 11, 2018

7. For more details, visit: https://en.wikipedia.org/wiki/Nachiketa

\section{References}

Anthias, F. (1998). Evaluating 'Diaspora': Beyond Ethnicity? Sociology,32(3). doi:https://doi.org/10.1177/0038038598032003009

Ashcroft, B. (2012). The Emperor's New Cloth (1158228578 870006533 M. Mukherjee \& 1158228579 870006533 H. Trivedi, Eds.). In 1158228577870006533 C. Vijayasree (Ed.), Nation in Imagination: Essays on Nationalism, Sub-Nationalisms and Narration (pp. 123-138). Hyderabad, India: Orient BlackSwan. 
Baranay, I. (2016). Transcultural Space and the Writer. Humanities,5(2), 28th ser. doi:doi:10.3390/h5020028

Bhaba, H. (1994). The Location of Culture. London and New York, NY: Routledge.

Bose, P. S., Sahoo, A. K., \& Lal, B. (2009). Home and Away: Diasporas, Developments and Displacements in a Globalizing World. In W. Safran (Ed.), Transnational Migration (pp. 136-163). New Delhi, India: Routledge.

Butt, N. (2008). Inventing or Recalling the Contact Zones? Transcultural Spaces in Amitav Ghosh's The Shadow Lines. Postcolonial Text, 4(3), 1-16.

Butt, N. (2015). Transcultural Memory and Globalised Modernity in Contemporary Indo-English Novels. Retrieved February 15, 2020, from https://books.google.co.in/books/about/Transcultural_Memory_and_Globalised_Mode.html?id=6 CyCCgAAQBAJ\&source $=$ kp_book_description\&redir_esc $=y$

Cardoso de Lemos, Gisele. (2016). Questioning the Western idea of reason through Hindu philosophy: An analysis of The Circle of Reason by Amitav Ghosh. International Journal of Dharma Studies, 4(6), 123.

doi: 10.1186/s40613-016-0032-x

Chambers, C. G. (2003). The Relationship Between Knowledge and Power in the Work of Amitav Ghosh (Unpublished doctoral dissertation). University of Leeds.

doi:https://www.academia.edu/5335239/PhD_Thesis_The_Relationship_Between_Knowledge_and_ Power_in_the_Work_of_Amitav_Ghosh

Clifford, J. (1997). Routes: Travel and Translation in the Late Twentieth Century. Cambridge, USA: Harvard University Press.

Cohen, R. (1997). Global Diasporas. London \& New York: Routledge.

Cohen, R. (n.d.). Solid, Ductile and Liquid: Changing Notions of Homeland and Home in Diaspora Studies. Caderno CRH,21(54), 519-532. http://dx.doi.org/10.1590/S0103-49792008000300008

Dagnino, A. (2013). Global Mobility, Transcultural Literature and Multiple Modes of Modernity. The Journal of Transcultural Studies,4(2), 130-160.

Dagnino, A. (2015). Transcultural Writers and Novels in the Age of Global Mobility. West Lafayette, Indiana: Purdue University Press.

Das, S. (2013). Contextualizing Identity in Amitav Ghosh's Novels (Unpublished doctoral dissertation). The University of Burdwan.

doi:http://shodhganga.inflibnet.ac.in/bitstream/10603/50481/1/sukanta\%20das\%20thesis.pdf

Daiya, K. (2008). Home and the Nation: Women, Citizenship, and Transnational Migration in Post-Colonial Literature. Journal of Post-colonial Writing,44(4), december, 391-402. doi:https://doi.org/10.1080/17449850802410507

Desai, A. (2014, January 22). Book review: The Circle of Reason by Amitav Ghosh. Retrieved April 10, 2017, from http://indiatoday.intoday.in/story/book-review-the-circle-of-reason-by-amitavghosh/1/348235.html

Goh, Robbie B. H. (2013). Inner Circles and the Voice of the Shuttle: Native Forms and Narrative Structure in Amitav Ghosh's The Circle of Reason. In Chitra Sankaran (Ed.), History, Narrative, and Testimony in Amitav Ghosh's Fiction (pp. 205-217). Albany, NY: SUNY Press. 
Ghosh, A. (1989, January 01). The Diaspora in Indian Culture. Retrieved February 15, 2018, from https://read.dukeupress.edu/public-culture/article-abstract/2/1/73/32011/The-Diaspora-inIndian-Culture?redirectedFrom=PD

Ghosh, A. (2008). The Circle of Reason (1986). New Delhi, India: Penguin Books \& Ravi Dayal Publisher.

Hawley, J. C. (2005). Amitav Ghosh: An introduction. New Delhi, India: CUP.

Jain, J. (2015). The Diaspora Writes Home:Subcontinental Narratives. Jaipur, India: Rawat Publications.

Mondal, A. A. (2010). Amitav Ghosh. New Delhi, India: Viva Books.

Rushdie, S. (2010). Imaginary homelands. Vintage, UK: London.

Safran, W. (1991). Diasporas in Modern Societies: Myths of Homeland and Return. Diaspora: A Journal of Transnational Studies, 1(1), spring(1991), 83-99.

Sarwal, A. (2016). South Asian Diaspora Narratives Roots and Routes. Jaipur, India: Rawat.

Sharrad, P., \& Kumar, T. (2012). Fabricating community: Local, National and Global in Three Indian Novels. In 1158117739869936074 C. Vijayashree, 1158117740869936074 M. Mukherjee, \& 1158117741 $869936074 \mathrm{H}$. Trivedi (Eds.), Nation in Imagination: Essays on Nationalism, Sub-Nationalism and Narration (pp. 212-228). Hyderabad, India: Orient Blackswan.

Srinivasan, R. T. (2017). Thinking "What We Are Doing": V. S. Naipaul and Amitav Ghosh on Being in Diaspora, History, and World. South Asian Review,32(3), 2011th ser., 49-70.

doi:https://doi.org/10.1080/02759527.2011.11932848

Vortovec, S. (2009). Transnationalism. London \& New York: Routledge.

Dr. Ajay K Chaubey is an Assistant Professor of English and Head, Department of Humanities \& Social Sciences, National Institute of Technology, Uttarakhand, India. He has presented his papers in national and international conferences held in India and abroad. Dr. Chaubey visited NTU, Nottingham; the University of Leicester and York St. John University, York (United Kingdom) in June 2014 for paper presentations. 